Letter to the Editor

\section{South Asia is more vulnerable to COVID-19 pandemic}

\author{
Hom Nath Chalise ${ }^{1,2 *}$ \\ ${ }^{1}$ Faculty Member, Department of Public Health, Nobel College Affiliated to Pokhara University, \\ Sinamangal, Kathmandu, Nepal \\ ${ }^{2}$ Vice President, Population Association of Nepal, Kathmandu Nepal
}

\section{Dear Editor}

Coronavirus disease 2019 (COVID-19) which originated in China spread progressively all over the world [1]. On $11^{\text {th }}$ March 2020 WHO declared COVID-19 outbreaks as a pandemic [2]. As of $22^{\text {nd }}$ May 2020, there have been more than 5.3 million confirmed cases of COVID-19, with more than 340 thousand deaths and more than 2.2 million recovered [3]. Slowly, South Asia is also entering the ranks of COVID-19 affected regions. This region comprises more than $21 \%$ of the world's population which remains vulnerable to COVID-19 [4].

The first confirmed COVID-19 case in this region appeared on January 24 in Nepal from a Nepali student coming from China [5,6]. Sri Lanka and India reported first confirmed COVID-19 cases on January $27^{\text {th }}$ and $30^{\text {th }}$ respectively [4]. As of April 1, the total number of COVID-19 cases in South Asia was 3,649 which increased to 62,895 on May 1 and more than 200,000 on $21^{\text {st }}$ May. Similarly, total deaths increased from 71 on April $1^{\text {st }}$ to 1,772 on May $1^{\text {st }}$ and around 5000 on May 21 [4]. India is leading in terms of total numbers of confirmed COVID cases (more than 105,000) and deaths (more than 3500) [3]. Till now, no mortality is reported in Bhutan and only three deaths are declared in Nepal. So far, Bhutan seems to have been able to control COVID-19 cases. The number of COVID-19 cases is 516 in Nepal [4], but it is expected to increase rapidly with the increase of Nepalese workers returning from India and other countries [5,6]. Strict lockdown and the young population may be one reason for low mortality in South Asia.

South Asia is one of the world's poorest and most populous regions. The health care facilities of this region are also very weak. Each of South Asia's eight countries has one of the lowest numbers of physicians per capita. It ranges from 0.3 physicians per 1,000 people (Afghanistan) to just one physician per 1,000 people (Maldives, Pakistan, and Sri Lanka) [7]. At the best of times, there are too few healthcare workers with negligible resources. Due to such reasons, this region will still be much more vulnerable if the severe cases of COVID-19 increase.

\author{
More Information \\ *Address for Correspondence: Dr. Hom \\ Nath Chalise, Department of Public Health, \\ Nobel College Affiliated to Pokhara University, \\ Sinamangal, Kathmandu, Nepal, Tel: +977 \\ 9851012622; Email: chalisehkpp@gmail.com \\ Submitted: 14 May 2020 \\ Approved: 21 May 2020 \\ Published: 22 May 2020
}

How to cite this article: Chalise HN. South Asia is more vulnerable to COVID-19 pandemic. Arch Psychiatr Ment Health. 2020; 4: 046-047.

DOI: 10.29328/journal.apmh. 1001018

Copyright: (c) 2020 Chalise HN. This is an open access article distributed under the Creative Commons Attribution License, which permits unrestricted use, distribution, and reproduction in any medium, provided the original work is properly cited.

Check for updates

OPEN ACCESS

All these countries have imposed strict lockdown, border seal, and curfews amid the fears the virus will strike densely populated areas. Few studies have shown that the long prevalence of this pandemic has created different types of psychological disorders and chaos among people $[5,6,8]$. Media and some publications have also reported some cases of suicide in this region [9]. In such a juncture of the public health crisis, individuals, researchers, and public health officials should be very careful while receiving and providing effective communications [10] and health professionals also need to attend mental health counseling training [11].

Finally, as the data show, the numbers of COVID-19 cases and casualties are rising sharply on a daily basis and are estimated to be much higher than reported given the paucity of testing. The fight with COVID-19 is not going to be easy. There should be joint cooperation from all levels of stakeholders to win this pandemic.

\section{References}

1. Huang C, Wang Y, Li X, Ren L, Zhao J, et al. Clinical features of patients infected with 2019 novel coronavirus in Wuhan, China. Lancet 2020; 395: 497-506.

PubMed: https://www.ncbi.nlm.nih.gov/pubmed/31986264

2. WHO. WHO announces COVID-19 outbreak a pandemic. Date 2020 . Date accessed $5^{\text {th }}$ May, 2020. http://www.euro.who.int/en/healthtopics/health-emergencies/coronavirus-covid-19/news/news/2020/3/ who-announces-covid-19-outbreak-a-pandemic

3. Worldometer, coronavirus, COVID-19 coronavirus pandemic. https:// www.worldometers.info/coronavirus/? 
4. SAARC disaster management center, coronavirus disease (COVID-19) SAARC Region. http://www.covid19-sdmc.org/

5. Chalise HN. COVID-19 situation in Nepal. Arch Psychiatr Ment Health 2020; 4: 033-034.

6. Chalise HN. COVID-19 situation and challenges of Nepal. Asia Pacific Journal of Public Health. 2020. DOI: 10.1177/1010539520932709

7. World Bank. Physicians (per 1,000 people) accessed through https://data.worldbank.org/indicator/SH.MED.PHYS.ZS

8. Gautam R, Sharma M. 2019-nCoV Pandemic: A disruptive and stressful atmosphere for Indian academic fraternity. Brain Behav Immun. 2020; PubMed: https://www.ncbi.nlm.nih.gov/pmc/articles/PMC7151469/
9. Sharma S, Sharma M, Singh G. A chaotic and stressed environment for 2019-nCoV suspected, infected and other people in India: fear of mass destruction and causality. Asian J Psychiatr. 2020; 51: 102049. PubMed: https://www.ncbi.nlm.nih.gov/pmc/articles/PMC7146677/

10. Garfin DR, Silver RC, Holman EA. The novel coronavirus (COVID-2019) outbreak: Amplification of public health consequences by media exposure. Health Psychol. 2020. 39: 355-357.

PubMed: https://www.ncbi.nlm.nih.gov/pubmed/32202824

11. Lima CKT, de Medeiros Carvalho PM, Lima IAS, de Oliveira Nunes JVA, Saraiva JS, et al. The emotional impact of Coronavirus 2019nCoV (new Coronavirus disease). Psychiatry Res. 2020: 287: 112915. PubMed: https://www.ncbi.nlm.nih.gov/pmc/articles/PMC7195292/ 